IRSH 60 (2015), pp. 4I 3-448 doi:I0.10I7/S00208 590I 5000498

(C) 2015 Internationaal Instituut voor Sociale Geschiedenis

\title{
Reproducing or Contesting the Global? Belgian Organized Consumerism and its International Entanglements (1957-1995)*
}

\author{
Gis E L L E N T H \\ Ph.D. Fellow of the Research Foundation Flanders, \\ Department of History, Ghent University \\ Correspondence address: \\ Universitair Forum, Universiteit Gent \\ Sint-Pietersnieurestraat 35, 9000 Ghent, Belgium \\ E-mail: Giselle.nath@ugent.be
}

\begin{abstract}
Between I957 and I984, Belgian consumers were represented by two comparative testing organizations: Test-Achats and the Union Féminine pour l'Information et la Défense du Consommateur. These two consumer organizations were fundamentally dissimilar in terms of their staff, their audience, and their ideological framing of consumer interests. Only the "politically independent" Test-Achats joined the International Organization of Consumer Unions (IOCU), even though it was initially smaller and weaker than the Union Féminine, the social-democratic alternative for consumers. A comparative analysis of Belgian organized consumerism reveals how, after 1957, the consumer interest was gradually reframed to fit a hegemonic definition. A private and commercial model of consumer representation was actively promoted over and against a public model through a complex transatlantic dialogue. Moreover, I argue that the international connections - or lack thereof - of the two organizations are essential to explain their success (or failure). The diffusion of organized consumerism during the I950s and I960s was financially and ideologically connected with the Keynesian-Fordist regulatory framework. The attack on embedded liberalism in the late i970s thus posed serious challenges. Mapping the choices and trajectories of Belgian consumer activists in an international context helps us to understand these challenges better.
\end{abstract}

\footnotetext{
* Earlier versions of this article were presented at the workshop "On the Dialectics of Global Governance Models: A Polanyian Double Movement?", held at the Ghent Centre for Global Studies (3 I March 20I4), and at the roth European Social Science History Conference in Vienna (23-26 April 20I4). I would like to thank all the participants in these sessions, and the anonymous reviewers of the first drafts.
} 
In recent years, research on the subjectivities and practices of consumers has blossomed in the social sciences. Historians have focused on the politics of consumption, showing more interest in the first half of the twentieth century than in the second. ${ }^{\mathrm{I}}$ This first phase was seen as the era of the self-conscious citizen-consumer: cooperative movements, participation in food riots, and the struggle of the working class to obtain material well-being all expanded the notion of citizenship. With such a reference point, the post-I945 period appeared to display merely the rise of the customer-consumer, i.e. the affluent, non-political shopper. ${ }^{2}$

This picture of post-1945 decline in the politicization of consumption together with generalized affluence is incomplete, however. It ignores not only the data from available welfare indicators but also the enduring importance of class differentiation. Recent analyses that view mass consumption in a socio-historical context have indeed shown the unexpected relevance of the postwar period. ${ }^{3}$ On the one hand, scholars connected everyday purchasing choices to political visions of society made after World War II. The seminal works of Liz Cohen, Matthew Hilton, and others on the mass consumer society have thus revealed that mass consumption continued to be related to social mobilization in the affluent West. ${ }^{4}$ This so-called organized consumerism was a social force in its own right because it changed the perception of culture and the nation. On the other hand, scholars such as Sheryl Kroen and Robert Haddow have illustrated how the United States government used consumer culture as a silent ambassador for democratic ideals - or more accurately, liberal ideas shaped by the Cold War context. ${ }^{5}$ This article bridges

I. For a general survey of the politics of consumption, see the contributions in Martin Daunton and Matthew Hilton (eds), The Politics of Consumption: Material Culture and Citizenship in Europe and America (Oxford, 200I). On consumer subjectivities see: Paddy Dolan, "Developing Consumer Subjectivity in Ireland, 1900-1980", Journal of Consumer Culture, 9 (2009), pp. I I7-I4I. Important studies on the first half of the twentieth century can be found in: Belinda Davis, Home Fires Burning: Food, Politics, and Everyday Life in World War I Berlin (Chapel Hill, NC, 2000); Tyler Stovall, Paris and the Spirit of 1919: Consumer Struggles, Transnationalism and Revolution (Cambridge, 2012).

2. Sheryl Kroen, "A Political History of the Consumer", The Historical Journal, 47 (2004), pp. 709-736, 728 .

3. See, for instance, John Brewer and Frank Trentmann (eds), Consuming Cultures, Global Perspectives: Historical Trajectories, Transnational Exchanges (Oxford, 2006); Jan Logeman, Trams or Tailfins? Public and Private Prosperity in Postwar West Germany and the United States (Chicago, IL, 20I2); Rebecca Pulju, Women and Mass Consumer Society in Postwar France (Cambridge, 20I I).

4. Lizabeth Cohen, A Consumers' Republic: The Politics of Mass Consumption in Postwar America (New York, 2003); Matthew Hilton, Consumerism in Twentieth-Century Britain: The Search for a Historical Movement (Cambridge, 2003).

5. Sheryl Kroen, "Negotiations with the American Way: The Consumer and the Social Contract in Post-war Europe", in Brewer and Trentmann, Consuming Cultures, pp. 251-277; Robert Haddow, Pavilions of Plenty: Exhibiting American Culture Abroad in the I9sos (Washington DC, 
those two fields by connecting the national and international scales more directly. The case of Belgium will highlight the simultaneous existence of variants of organized consumerism but also the varying international insertion of the country's two consumer organizations.

Test-Achats (Testing Purchases, TA) and the Union Féminine pour l'Information et la Défense du Consommateurs (Women's Union for the Information and Defence of Consumers, UFIDEC) coexisted for almost four decades. ${ }^{6}$ They acted as the voice of the mass consumer in the welfare state and tried to raise consumer awareness in Belgium. To do this, both used the same instrument (or "product"): a periodical containing commodity tests and advice columns. Though very similar at first sight, closer scrutiny of both organizations reveals fundamental differences that had little to do with, say, laboratory techniques, but everything to do with politics. The UFIDEC was the result of cooperation between two women's associations pertaining to the social-democratic world, the female health insurance branch Femmes Prévoyantes Socialistes (Socialist Women's Provision Fund) and the Femmes Cooperatrices (Women's Cooperative Guild). They were the quintessential "old" social movements of the (female) working class. In contrast, TA was a project of (male) professionals connected to established elites and firmly oriented towards the middle class.

The first part of this article analyses the differences in functioning, composition, and trajectory of these two organizations. The second part focuses on the international scene. It highlights how the oppositional characteristics of each organization reflected the formation of a transnational hegemonial definition of the consumer interest. TA had a more privileged relationship with the American Consumers' Union (CU) and its International Organization of Consumers' Unions (IOCU) than the UFIDEC. The differences between the organizations were marked: while the UFIDEC stressed activism, collectivity, and the defence of consumer rights, TA was committed to providing the "intelligent individual" with "neutral" information. Despite the stark differences between a workingclass consumer movement and a more elitist, non-political consumer organization, this article will analyse both of them in terms of a social movement approach. To include consumer organizations (especially those that have tested and ranked commodities and sold the results in a periodical) in a broadened definition of social movements is somewhat contested. As Hilton notes: "if consumers act on their own, they are held to be powerful

1997); Cynthia Henthorn, From Submarines to Suburbs: Selling a Better America, 1939-1959 (Athens, OH, 2006).

6. The Belgian Association des Consommateurs has changed its official name several times, hence my use of the (French) name of its magazine, Test-Achats, as a shorthand for the entire organization. 
resisters of the dominant value system [yet] if they act collectively, they are discounted from a definition of what constitutes a social movement". ${ }^{\text {? }}$

There are indeed historical and methodological reasons to prefer the notion of "social movement" over other problematic concepts such as "civil society institution" or the pure and simple "organization" when analysing organized consumerism. Historically, consumer concerns have led to social mobilization (often on a massive scale) long before and after the heyday of comparative testing organizations (for instance, consumer cooperatives in earlier times or fair-trade activists in more recent ones). Hence, it does not seem to make sense to isolate testing organizations - and the period of the postwar boom during which they emerged - from this historical trajectory without at least asking why they employed an unfamiliar strategy and tone. It is my assertion that this broadened social movement approach helps us to assess the complex impact of these consumer organizations in relation to political debates of the Cold War period. Consumer movements were actors that translated general ideas and tropes of "modernization" into social movement practice. They mobilized the masses not primarily through ideology or class-based arguments but by providing what they saw as "modern", "non-political", and "efficient" services to their subscribers. Their preference for the notion of subscribers (rather than members) already suggests that consumer movements were the first to breach the previous repertoires of collective action.

Nonetheless, the sheer dimension and spread of these organizations confers a character of social mobilization on them. During the I960s, about one in three Belgian households was in regular touch with one of the two consumer advice periodicals. At its height during the 1970 S TA had 300,000 subscribers. ${ }^{8}$ Arguably, this made it the biggest middle-class movement in Belgian history. ${ }^{9}$ Those who sold product ratings to a broad audience could not have survived without capitalizing on a widespread desire to balance the interests of consumers with those of producers. Mass consumer society thus clearly galvanized some sort of discomfort, which led to different forms of intervening practices. While some of these were mainly top-down, others had a stronger grassroots character.

For the members of the UFIDEC, taking out a subscription was only one element of a broader commitment that included actively confronting retailers and manufacturers on their unacceptable commercial practices. Belgian local government was petitioned in the name of the

7. Matthew Hilton, "Social Activism in an Age of Consumption: The Organized Consumer Movement”, Social History, 32 (2007), pp. I 2 I-I 43.

8. University Archives Ghent, Archives Willy Van Rijckeghem, HSLS III. I32 [hereafter, UGhent WVR], i I, "Le budget 76/77", p. 2 I.

9. Paul Claeys, Groupes de pression en Belgique: les groupes intermédiaires socio-économiques. Contribution à l'analyse comparative (Brussels, I973), p. 259. 


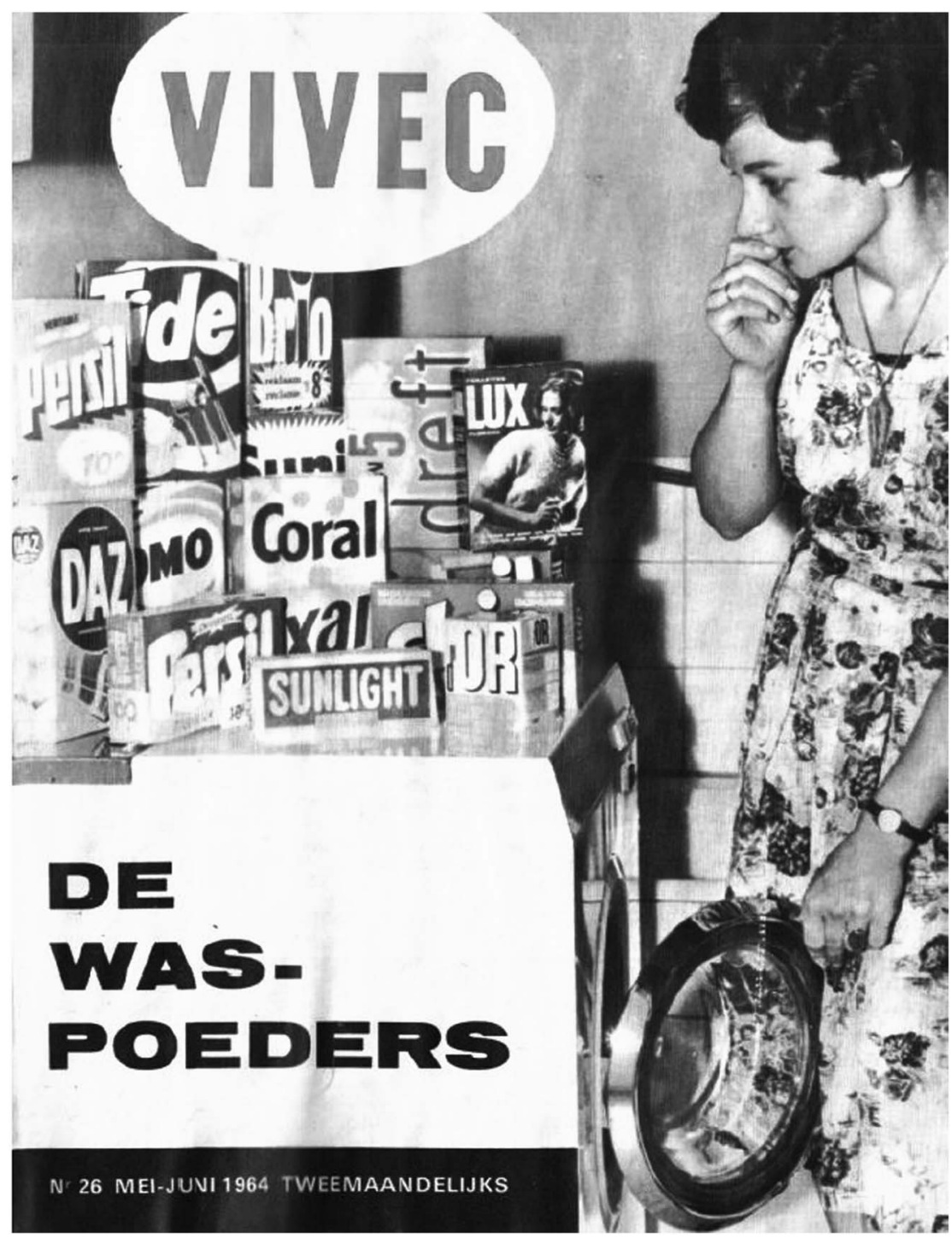

Figure I. Cover of the Dutch version of UFIDEC's periodical with a test of laundry detergents (1964).

consumer. ${ }^{\mathrm{IO}}$ Methodologically, the definition of a social movement can be made as inhibiting or as broad as the observer desires. However, all

Io. For local examples from Antwerp and Ghent, see Felix Archief (Antwerp), Archives Frans Detiège, 672/1772; and Lien Cole, "Vrouw en coöperatie. De coöperatieve vrouwenbond 'De Samenwerkster' in Gent” (M.A. thesis, University of Ghent, 20I 2). 
definitions stress that social movements accompany or stimulate social change, that they are the product of collective efforts, and that they provide a mixture of organization and spontaneity. ${ }^{\mathrm{II}}$ It might be objected that postwar organized consumerism was heavily institutionalized. This characteristic, however, was shared by the labour movement and the women's movement. Consumer advocates have participated, in their own way, in the consultative structures of the welfare state. They have based this intermediary position on the claim that they represented a critical number of members, on whose behalf they approached authorities or the media.

If TA seems a case quite distinct from most other social movements, this is because it depended to a very high degree on commercial success, and because it self-identified as a politically neutral movement. ${ }^{\mathrm{I2}}$ The need to be commercially successful was, of course, also a hallmark of the classic cooperative of the labour movement, yet membership of the cooperative nevertheless entailed a profile of social activism. ${ }^{13}$ Besides, consumer cooperatives promoted clearly recognizable political ideologies. While TA promoted an equally ideological vision of society, this vision was represented as neutral and non-political. For TA, the consumer interest was something that could be derived from a laboratory. The fact that its definition of the consumer interest rendered complex economic processes of capital accumulation or commodification invisible is, of course, highly significant. Its individual system of information worked well for those who had enough money and cultural capital, but it was prone to neglect more structural issues. Furthermore, in a private model for consumer defence, movements constantly had to beg the affluent consumer in order to survive. These choices were debated among the historical actors themselves. Internal discussions between TA's management and staff reveal how the boundaries between social movement and "neutral" interest group were continuously questioned, with the latter being the preferred model of TA's founding fathers. ${ }^{\mathrm{I}} \mathrm{Few}$ other European consumer movements were devoted so intensely to running organized consumerism like a company. The Belgian case thus highlights a clash between "modern" mid-century technocratic ideals and a long-established working-class approach to mobilization. As such, the comparative testing movement provides an excellent mirror to observe broader changes in the sphere of social and political organizations.

I I. See David Snow, Sarah Soule, and Hanspeter Kriesi, "Mapping the Terrain”, in idem (eds), The Blackwell Companion to Social Movements (Malden, 2004), pp. 3-I6, 3; "Social Movement", Encyclopedia Britannica Online, http://www.britannica.com/topic/social-movement, last accessed January 2015 .

I 2. See, for example, Yvan Langaskens, "Beschouwingen over de toestand van de verbruiker in onze maatschappij”, Economisch en Sociaal Tijdschrift, I7 (1963), pp. 2 I 3-220.

I3. For a survey of the historical research on consumer cooperatives, see Marcel van der Linden, Workers of the World: Essays Toward a Global Labor History (Leiden, 2009), ch. 7.

I4. See, for instance, the following minutes from the i970s: UGhent WVR, 3 , Board of Directors of TA, 2 April 1974 . 
The first part of this article uses a resource-mobilization approach to compare the historical development of TA and the UFIDEC from their foundation until the early i970s. ${ }^{\text {Is }}$ Four "resources" are further analysed: management and leadership, financing, membership composition, and the message that both movements delivered to their rank and file. This comparison underscores the tight relation between national European events and the public-private nexus in international diplomacy. United States government officials pushed for what John Ruggie has termed "embedded liberalism" in Europe; organized consumerism was part and parcel of this effort. ${ }^{16}$ The Consumers' Union (CU), founded in 1936, became the quintessential expression of the Anglo-Saxon approach to consumerism. The transfer of the CU's model to Europe depended on the active role of Colston Warne, a professor of economics and the CU's longtime president. Public and private action were intertwined. ${ }^{17}$ But not all foreign activists reacted with equal enthusiasm to this example from abroad, and organized consumerism developed along different lines across Europe.

The second part of the article looks at the IOCU as a site of contention between national movements, rather than simply as a collective project of national movements. I reconstruct the IOCU's trajectory between I960 (when it was founded) and I995 (when the IOCU confirmed its principal endorsement of free trade at the Uruguay Round and the consequent World Trade Organization). From a static perspective, an advocacy group such as the IOCU contests a given economic reality, rather than confirming or reinforcing it. ${ }^{18}$ A historical analysis, however, shows that the IOCU had a much more ambiguous legacy. International civil society is not detached from the dynamics of power or the institutionalization of hegemony. This, in turn, had a great impact on which organizations entered the international scene in which way.

\section{EXPERTS VERSUS SOCIAL-DEMOCRATIC HOUSEWIVES: COLLECTING RESOURCES}

In the postwar period the bulk of Belgian consumers, and especially blue-collar workers, were inexperienced when it came to complicated

I5. Doug McAdam, John McCarthy, and Mayer Zald (eds), Comparative Perspectives on Social Movements: Political Opportunities, Mobilizing Structures, and Cultural Framings (Cambridge, 1996).

I6. J. Ruggie, "International Regimes, Transactions, and Change: Embedded Liberalism in the Postwar Economic Order”, International Organization, 36 (1982), pp. 379-4 I 5, 393.

17. On this nexus see, for instance, the contributions to Helen Laville and Hugh Wilford (eds), The US Government, Citizen Groups and the Cold War: The State-Private Network (London, 2006).

I8. Arnd Bauerkämper and Christoph Gumb, “Towards a Transnational Civil Society: Actors and Concepts in Europe from the Late Eighteenth to the Twentieth Century", Discussion Paper of the Wissenschaftszentrum Berlin für Sozialforschung, No. SP IV 2010-40I (2010). 
personal purchases. Moreover, professional sellers often lacked customer orientation. ${ }^{19}$ This situation was exacerbated through the so-called productivity missions to the USA, paid for by the postwar Marshall Plan. In Belgium, the Office Belge pour l'Accroissement de la Productivité (OBAP) was responsible for distributing these so-called Marshall Plan funds. The OBAP, a conglomerate of Belgian civil society groups overseen by the Ministry of Economic Affairs, funded the study missions that Belgian producers or retailers suggested as the most rewarding. None of these actors took much notice of consumer rights. One mission report enthusiastically described how in America "novelty" packaging allowed producers to diminish product weight since "consumers were compensated with a fun packaging". ${ }^{20}$ American officials themselves became increasingly disconcerted over the lack of genuine interest in the consumer. In 1956, a Dutch team was the first group to tour America on a mission devoted entirely to the consumer interest. ${ }^{21}$ The State Department also sent numerous European delegations to the CU in New York and made sure that their "Consumers' Reports" were available in the embassies. ${ }^{22}$ Triggered by these events, Colston Warne of the CU travelled to Europe to see how he could promote this new interest in consumer advocacy. Around 1958, he convinced the Organization for European Economic Co-operation to hold a conference on the topic of comparative testing. ${ }^{23}$

Consequently, many western European consumer movements were linked to government officials involved in Marshall Plan management. The French and Dutch officials André Romieu and Bartholomeus Buitendijk founded consumer movements in their respective countries, not only because the American example reached them first, but also as a reaction to the far-reaching changes in the European economy. ${ }^{24}$ The Belgian founder of TA was connected to the OBAP in a more informal way. ${ }^{25}$ TA was set up

I9. James Obelkevich, "Americanisation in British Consumer Markets, I950-2000", in Matthias Kipping and Nick Tiratsoo (eds), Americanisation in 2oth Century Europe: Business, Culture, Politics (Lille, 2002), p. 74.

20. National Archives, Brussels, OBAP 360, Verslag zending public relations-publiciteit. Belgische zending naar de VS, I955, pp. 20, 43, and I09. All translations from Dutch and French are my own.

21. Welvaart en Consumptie. Rapport van de Commissie Opvoering Productiviteit (The Hague, 1956).

22. Consumers' Union, New York, Colston Warne Papers, I4/4, Warne to Peterson, is February 1960.

23. Kansas University, Consumer Movement Archives, Colston Warne (6/I), Proceedings of the 2nd Institute on Consumer Problems, I0-I I September 1956 (unpublished research paper), p. 27. 24. Johan van Merriënboer, "De moeizame start van de Consumentenbond", Politieke Opstellen, I 8 (1998), pp. 52-69, 54. The French and Dutch consumer movements were founded in 1953 and I95 I respectively.

25. Willy Van Rijckeghem, L'histoire de Test-Achats. D'une revue de consommateurs à une multinationale (Brussels, 2005), p. I I. 
in December 1957 by Louis Darms, a Brussels-based advertiser, whose boss had previously participated in an advertising mission to the USA; Darms also knew the OBAP's president well. In February 1958, the OBAP decided to send a mission to the Netherlands on the theme of consumer interest representation. Just a few days before the mission was scheduled to depart, the Women's Cooperative Guild received an invitation too; the socialdemocratic trade union had passed their own invitation on. The women were clearly not at the centre of events, but they were still very enthusiastic.

After the mission, several Belgian civil society movements (including associations of Catholic women) planned to cooperate in a common national consumer institute, to be sponsored with I million Belgian francs (BEF) by the OBAP. The social-democratic women were not yet planning an independent organization, and Darms was seemingly not opposed to cooperating with more established partners, such as the social-democratic women and the Family League. Yet the proposition came to nothing, not least because the OBAP was dominated by producer and retailer associations. Government funding was withheld. The women thus started their own organization, the UFIDEC, in I959. At this point it had already become clear that Darms's view of consumers as "non-political" and his belief that a consumer organization catered mostly for the educated middle class by providing information clashed with the social-democratic interest in a more combative defence of the financially hard-pressed blue-collar consumer. ${ }^{26}$ Moreover, the UFIDEC had good perspectives. While Darms had a movement only on paper (with 30 subscribers in 1958 and 250 in I959), the UFIDEC could count on the funding and the loyal rank and file of the social-democratic "pillar". ${ }^{27}$ In 1959 the UFIDEC proudly announced that it represented about 500,000 women and their families. ${ }^{28}$ This figure, however, was the sum of the membership of the Women's Cooperative Guild and the Femmes Prévoyantes Socialistes, rather than the number of subscribers to the UFIDEC's periodical pure and simple. Though this had consequences later on, it had little bearing for TA's position, which was simply disadvantaged compared to the UFIDEC. So what tipped the scales in the end?

26. For Darms's vision see: UGhent WVR, i I I, Political charter of TA by Darms.

27. The term "pillar" refers to a regionally specific variant of corporatism and denotes a relatively closed network of organizations belonging to the same ideological and/or denominational sphere. In the postwar period, daily life in Belgium and the Netherlands was heavily coloured by the influence of these pillars, while similar constellations could also be found in Austria, Germany, and Scandinavia. Today, what remains of them is commonly referred to as the societal midfield or "civil society institutions". A classic analysis of the pillars can be found in J.P. Kruyt, "Sociologische beschouwingen over zuilen en verzuiling", Socialisme en democratie, I4 (I957), pp. I I-29.

28. Christine Matton, "La défense des consommateurs en Belgique de I957 à I984: Ufidec et TestAchats" (M.A. thesis, Université Libre de Bruxelles, 2005), p 7I. 


\section{Leaders and management}

TA made a sweeping start by enlisting a professional team for its management. Darms was able to enlist powerful people for his project because he had organized the successful 1958 electoral campaign of the powerful Catholic Party. ${ }^{29} \mathrm{He}$ worked in the Ministry of Defence and noticed that the laboratory of the Belgian army already practised comparative product testing. His network thus provided an easy entry point into the world of professional testing. Darms's friend Gilbert Castelain, president of the Brussels local division of the Catholic Party and a notorious anti-socialist, became TA's director. Other important board members were young upcoming professionals, such as economist Willy Van Rijckeghem (a future university professor), engineer Jacques Neirynck (who would later emigrate to Switzerland and become a politician for the Swiss Christian Democrats), engineer Hugues du Roy du Blicquy, and Catholic politician Manu de Bethune, both of noble extraction. These stalwart board members also recruited a patronage committee, including Betty Barzin of the Belgo-American Association and conservative former ministers. Through this patronage committee, TA easily reached target groups such as female journalists, home education teachers, and the academic world. Most of these connections could also mobilize enough venture capital to contribute to TA when the financial situation turned bad. Remarkably, legal professionals were initially absent from the organization, despite the obvious potential of their expertise for consumer protection. It was not until 1979 that a young academic lawyer joined TA's board (he quit only a few years later). Conflicts arose because his University Centre for Legal Studies, which took an interest in consumer protection, was considered a competitor. ${ }^{3 \circ}$

Meanwhile, the social-democratic women had ample commitment, but little time or specialized expertise, let alone venture capital of their own. Being at the same time indispensable to the functioning of their own associations, UFIDEC leaders could not commit to the UFIDEC on a daily basis, especially when taking up a parliamentary mandate or running their household alongside. Irène Pétry and Jeanne Vanderveken, two of the driving figures behind the UFIDEC, are both a case in point: pioneering parliamentarians, hard-working women of humble origins, but in general less well-educated and representing a rank and file of ageing women. ${ }^{3 \mathrm{I}}$

29. Belgium's Christian Democratic Party was split into progressive and conservative wings. The progressive side adhered to the Christian Democratic trade union, which was catching up numerically with the social democrats. The conservative wing included a traditional electorate of rich and well-established Catholic families. My use of the term Catholic Party reflects the dominance of this conservative wing in the r950s and early i960s.

30. Van Rijckeghem, L'Histoire de Test-Achats, pp. I46-I 47.

3. University education was not available to children of the average blue-collar worker at the time. Kenneth Bertrams, "From Exchange Programmes to the Legitimization of University-based 
Everyday management of the UFIDEC was delegated to Paul Richely, a chemist who became its life-long spokesman. Unlike Darms and Castelain, Richely was a rather isolated actor with very little influence in society. $\mathrm{He}$ was a chemist who worked in the cooperative laboratory of Liège. He was hired because he endorsed the cooperative ideals and had the technical expertise to conduct food tests. These food tests were exactly the issues that were fundamental for the UFIDEC but which Darms had considered insufficiently interesting for TA. ${ }^{32}$

The attitudes of these social movement actors differed considerably. The commitment of social-democratic militants towards their local working-class communities clashed with the international orientation of the professionals in TA. The latter were very eager - and due to their professional position, more able - to get in touch with "modern" American examples. ${ }^{33}$ Darms and Castelain relied on the most sophisticated marketing techniques available to make TA known, such as direct mailing, galvanizing elite target groups to promote the message to other groups, and enticing readers with gifts. These were all deemed part of the "modern" Anglo-Saxon approach to advertising. ${ }^{34}$ As the brainchild of advertisers, TA was not afraid to use the same marketing tricks it denounced producers for. ${ }^{35}$ Castelain stated that "in the States, which I visited regularly, I decided to manage TA like a business". ${ }^{36}$ Meanwhile, the women of the UFIDEC depended on the more artisanal techniques of propaganda, such as word of mouth by an enthusiast rank and file. Even though they occasionally used radio messages and mass mailings to teachers, most of the members were recruited in a more traditional labour-movement fashion. Key figures gave lectures in factories or neighbourhood get-togethers, stencilled notes were disseminated, and there was even a didactic play organized. These measures

Management Education: The Case of Belgium, 1920-1970", in Kipping and Tiratsoo, Americanisation in 20th Century Europe, pp. 225-24I, 229. Irène Pétry could follow secondary education (in economics) only until her eighteenth birthday. During the interwar period, she was granted one week of training at the Ecole Ouvrière Supérieure in Brussels; she then worked continually for the Social Democratic Party. See "Irène Pétry", in Helmut Gaus (ed.), PolitiekBiografisch Lexicon: Belgische Ministers en Staatssecretarissen (I960-1980) (Antwerp, I989), p. 883 .

32. UGhent WVR, i i , Political charter of TA by Darms.

33. The formation of a transatlantic group of technocrats with considerable influence on their national societies was explored by Kees van der Pijl, The Making of an Atlantic Ruling Class (London, 1984). A more institutional exploration of these linkages in Belgium can be found in Kenneth Bertrams, Universités et entreprises. Milieux académiques et industriels en Belgique, I880-1970 (Nivelles, 2005), pp. 419-423.

34. UGhent WVR, 44, interview with Gilbert Castelain by Jean Blavier, 1992, passim.

35. Advertising and promotion formed the major cost item in the TA's early budgets, accounting for 32 per cent in 1961. By comparison, the UFIDEC spent 4 per cent of its total budget on advertising in 1960 .

36. UGhent WVR, 44, interview with Castelain by Blavier, p. 56. 
were not necessarily less effective at the time. In one case, one woman brought in ro० new members after a single passionate talk about consumer defence. ${ }^{37}$ Still, TA was clearly using the more novel means to reach their goals.

\section{Finances}

The second major resource to be mobilized by the two organizations was the financial means to pay for tests, employees, and publications. The UFIDEC was sponsored by six organizations within the social-democratic pillar, and especially by the cooperative movement, which still had considerable budgets during the I950s. In I959 the UFIDEC was thus assigned BEF 800,000 by these organizations. This tutelage by established organizations of the social-democratic labour movement, all of them maledominated, entailed two things. First of all, it made Richely take a very defensive attitude towards finances. Tensions mounted because regional cooperative managements and the trade union did not always support the new project, reflecting gendered prejudices about the benefit of this activity. Secondly, income did not double or triple even though membership did. This curbed investments and caused the gradual stagnation of the UFIDEC. While TA expanded its number of employees to twenty-six after 1968, the UFIDEC never had more than ten paid employees. ${ }^{38}$ Despite these limitations to expansion, immediate decline was averted mainly because the socialist pillar was such a large, firmly embedded mass movement. Meanwhile, TA had to incur serious debts and was constantly on the verge of bankruptcy. The (more expensive) direct mailing campaigns and the cost of their glamorous magazine further contributed to this.

TA continually stressed that it was financed only through the subscriptions of its members, in order to guarantee independence from industry, government, or political parties. This non-aligned character was presented as its unique selling point. Yet during the early years, members were not a reliable source of income. Instead, Darms was able to get acquainted with Colston Warne of the CU and Caspar Brooks of the British Consumers' Association (CA). This connection literally paid off: TA's sources indicate that at the beginning of the r 960 s they obtained a loan of about BEF 200,000 from the British CA and a grant from the CU of about I $25,000 .{ }^{39}$

37. Amsab - Institute of Social History, Ghent, Archives of the Cooperative Women [hereafter, Amsab Coop], I6I, Board Meetings, I I May I959 and 5 October 1962.

38. By 1984, by which time the UFIDEC had been closed down, only Richely, another chemist, a secretary, and a technician were left as regular employees. See Matton, "La défense des consommateurs", pp. 73 and 98, and Matthijs Driessen, "Vivec/UFIDEC 1959-1984" (M.A. thesis, Free University of Brussels, 2014), pp. 83-100 and 105.

39. UGhent WVR, I I 4 , letter to the board members, I96 I "strictement confidentielle"), and I I 3 , "budget I962". These figures are contested because in a 1992 interview Castelain spoke of even 
Matthew Hilton's archival research has furthermore shown that TA actually

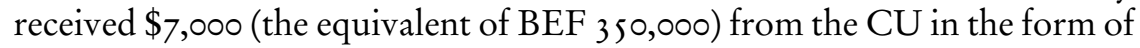
a grant, as did similar consumer organizations in the Netherlands and Israel. ${ }^{\circ}$ TA's well-heeled board members also contributed through loans.

How had these transatlantic connections been established? In 1956 Warne had asked Oscar Peterson, labour officer at the American Embassy in Brussels and his close personal friend, about interesting developments in Belgium. He ended up meeting with Darms, while missing his appointment with the UFIDEC representative. ${ }^{{ }^{\mathrm{I}}}$ It seems that Darms, the professional advertiser connected to the government, was better known in the small, elitist social environment that circled the American Embassy. While Florence Mason, Warne's colleague at the CU, later wrote enthusiastic reports of the UFIDEC's efforts, Warne himself always seemed to be on the side of Darms. Perhaps he had identified this independent movement as the most promising project, ${ }^{42}$ even though alarming reports reached him about the incompetency of both Darms and Castelain later on. ${ }^{43}$ Social gulfs and a shared culture of sociability played a role, too, as Warne probably found it easier to socialize with people of his own background. To put it bluntly, he was a well-off academic who participated in meetings at the Waldorf Astoria hotel, the unofficial palace of New York. When travelling to Belgium, Darms and du Roy du Blicquy organized a cocktail party for Warne, leaving him much impressed. ${ }^{44}$ This was not at all the social-democratic style of entertaining guests. Warne certainly reasoned that TA, despite its shortcomings, had a good sense of publicity. He was already planning to set up the IOCU and he needed convincing, prestigious partners to gain credibility among UN officials.

But even with the foreign bailouts and after doubling the price of a subscription, TA's membership did not grow fast enough to cover debts.

larger sums: BEF 250,000 given by the CU and BEF 250,000 by the IOCU (p. 28). But these financial sources are mentioned only after the sums given by Belgian board members, indicating that Castelain did not feel comfortable revealing these foreign sources. See UGhent WVR, 44, interview with Castelain by Blavier, p. 28.

40. Van Rijckeghem, L'Histoire de Test-Achats, p. 27, and Matthew Hilton, Prosperity for All: Consumer Activism in an Era of Globalization (London, 2009), pp. 22, 36-37.

4I. Consumers' Union, New York, Colston Warne Papers, 38/7, letter from Warne to Peterson of 6 February 1956, and 27/I, letter from Richely to Warne, I3 October I959.

42. In that, Darms of course played an active role by indicating to Warne that the UFIDEC, connected with the cooperative movement, could potentially have more interest in the distribution of cooperative products.

43. Consumers' Union, New York, Colston Warne Papers, 22/8, letter from Van Veen to Warne, 30 September 1964: "it seems to me that the last issue of Test-Achats can hardly be considered a good product", and 27/8, letter from Mason to Warne, 26 October 1964.

44. Consumers' Union, New York, Colston Warne Papers, 38/7, letter from Warne to Darms, i9 March i965. 
TA thus attempted to rely on other, stronger partners. This and the position taken by Colston Warne, who despite his sympathies for the independent type of consumer organization still wanted to see a unified Belgian consumer movement, led to renewed negotiations between TA and the UFIDEC in the early I960s. They planned to set up a National Federation of Consumer Groups and launch a two-week public event to raise awareness. ${ }^{45}$ But when Richely proposed that they jointly undertake a test of a durable commodity, Castelain refused outright. Caught up in the commercial logic, he did not want UFIDEC subscribers, who paid only 20 francs per year, to obtain the same information for which his own members paid roo (later 200) francs. The ideological gulf proved unbridgeable and talks failed. At a certain point, the American push for closer cooperation waned. Warne had initially stated that TA would no longer receive money from the CU unless they cooperated with the UFIDEC to form a strong, unified movement. Darms replied to Warne that TA was the only truly “independent" consumer movement. He claimed that the UFIDEC would politicize consumer defence and implored him to leave the idea of a merger behind, arguing that "[only] we speak the same language". ${ }^{6}$

In a similar attempt, Castelain hoped that the Family League would cooperate with TA. But again, he refused them the right to undertake tests of their own. ${ }^{47}$ Lacking a further-reaching social message, TA had only the novelty of technical tests, which it defended aggressively. The international connections served this purpose well. Darms succeeded in uniting the British and the Dutch in a European testing group, which operated informally at first but became a fully fledged European Testing Group (including a collectively financed laboratory managed by TA in Belgium) during the I970s. While TA was in that way able to produce elaborate tests and cut costs, the UFIDEC was increasingly isolated and forced to do cheaper tests. When Richely asked to borrow one of the joint Euro tests on domestic irons, Castelain again refused..$^{4}$ The Family League, too, never pioneered high-tech testing but survived by cooperating with producer-led standardizing bodies. The most decisive move, however, was the agreement that TA made with the Catholic pillar in I964. That year, the trade union Mouvement Chrétienne Ouvrière (MOC) gave up plans to found a

45. UGhent WVR, I I4, Board Meetings, is November 196I and I2 December I96I, and I I3, "quinzaine du consommateur".

46. Consumers' Union, New York, Colston Warne Papers, 38/7, letter from Darms to Warne, I9 March 1965 .

47. UGhent WVR, 44, interview with Castelain by Blavier, p. 78; г I3, letter from Willy Van Rijckeghem to Frans Van Mechelen, July i 962; and i i6, "Note préliminaire de Castelain" and "Elements de base de l'action consommateur".

48. UGhent WVR, i is, Board Meeting, i7 March I965, and i i6, Board Meeting, i7 January 1967. 
consumer movement of its own in exchange for a seat on TA's board. This political alliance provided TA with some access to the financial resources and large rank and file of the Catholic pillar. ${ }^{49}$ The agreement was never made public and TA continued to flaunt the image of complete independence and to attack the UFIDEC as not "truly independent". ${ }^{\circ}$

\section{Subscribers}

Few consistent data are available on the rank and file, the third major resource of any social movement. What is known is that TA was not able to overtake the UFIDEC numerically until after 1969. The UFIDEC's membership began to dwindle seriously after 1979. While Castelain claimed that he knew people who subscribed to both magazines, it rather seems, as the political scientist Paul Claeys argued in the I970s, that the two movements spoke to a distinct audience. ${ }^{\text {I }}$ Considering the price of the magazines, this makes sense. In 1967, a one-year subscription to the UFIDEC cost BEF 20, while a subscription to TA was ten times as expensive. TA's rank and file was firmly middle-class: most of the subscribers were male, relatively advanced in age, heads of household, and generally more highly educated.

With such a readership profile, TA exhibited the same bias that characterized comparative testers worldwide. The UFIDEC, recruiting among a more female working-class audience, was an exception. ${ }^{52}$ The Belgian case also suggests that the difference between the two constituencies was due not only to the subscription price but also to the tone and vision of the editors. A I975 publication co-edited by Willy Van Rijckeghem, a TA board member, featured an article on the consumer movement. In the article, the middle-class bias of TA's magazine was attributed to the "consumerist consciousness, which is inherent to higher qualified groups who are more detached from the

49. From then on, TA undertook more expensive tests rather than borrowing the tests conducted by the British CA. It also made its first profits. See UGhent WVR, i I , Board Meeting, 28 June I965; Van Rijckeghem, L'Histoire de Test-Achats, p. $5 \mathrm{I}$.

50. The existence of the agreement was in fact denied even during the I970s. See Claeys, Groupes de pression en Belgique, p. 307. The alliance with the Catholic pillar brought TA even closer to a certain idea about household management and the gendered division of labour: the Catholic pillar adhered to the dominant wage-earner/housewife model more strictly than other groups and saw consumer advocacy and the right choices in consumption as a way to get women interested in the Catholic faith and the political programme of the Catholic pillar. See Emmanuel Gerard, De christelijke arbeidersbeweging in België I89I-I99I. Deel I (Leuven, I99I), pp. 362-376; and Valérie Piette and Eliane Gubin, "Travail ou non-travail? Essai sur le travail ménager dans l'entredeux-guerres”, Revue belge de philologie et d'histoire, 79 (200I), pp. 645-678.

5. Claeys, Groupes de pression, p. 295.

52. This pattern was corroborated in Jean-Marcus Steiff, "L'information comme mode d'action des organisations de consommateurs", Revue française de sociologie, I 8 (1977), pp. 85 -107, 9 I. 


\section{Social-professional profile of subscribers to Test-Achats (1970).}

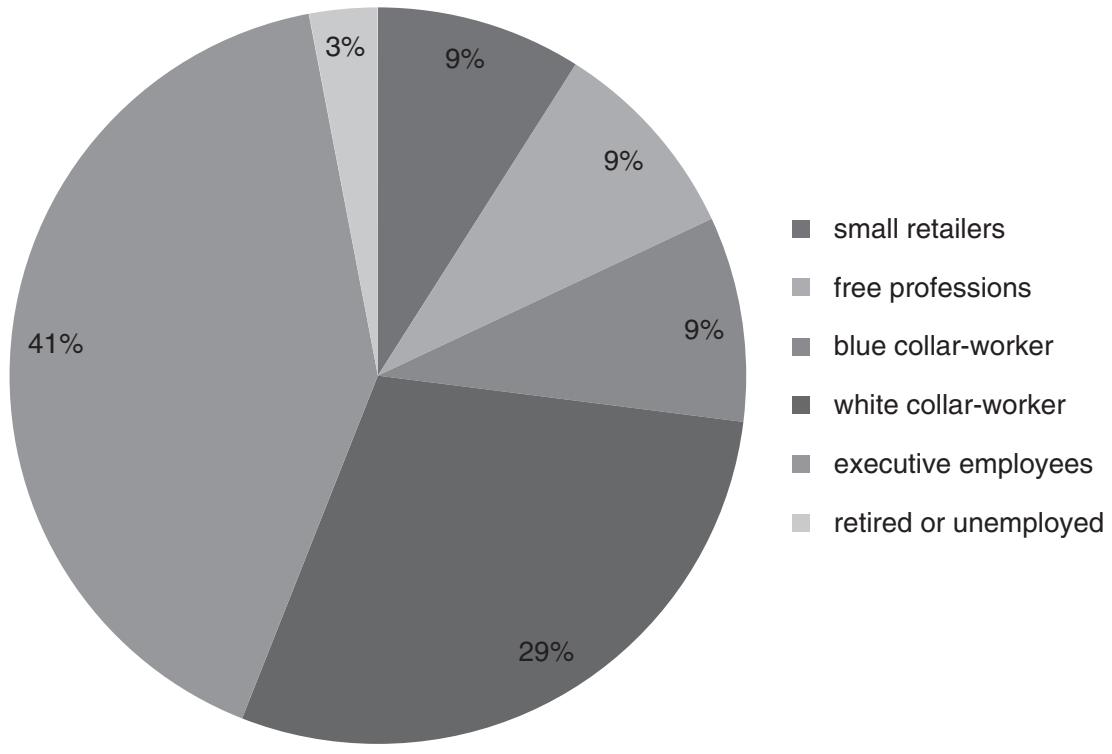

Figure 2. Social-professional profile of subscribers to TA (1950).

Source: Survey by Test-Achats, reprinted in Bohets, Het land waarin wij werken.

production process"..$^{3}$ Rather than a sound sociological consideration, such a statement reflected the need for social distinction and the entrenched prejudices against the working class, who had, as numerous examples of mobilization from earlier periods show, as many stakes in consumer issues as any other group. TA staff members also consistently represented their own movement as the only consumer movement, thus rendering others invisible. ${ }^{54}$ The Belgians were not alone in doing so. The British Consumers' Association did not include cooperative products in its testing samples, apparently because they were not part of the "new" and "modern" markets that the Association wanted to promote through comparative testing. 55

53. Jan Bohets (ed.), Het land waarin wij werken. Een doorlichting van het Belgisch economisch systeem (Antwerp, I975), p. I68. This volume was a collection of texts by ten Belgian economists. The authorship of specific chapters or sections was not given; however, it is plausible to suppose that Van Rijckeghem authored the sections about consumerism.

54. It was also stated that "unlike traditional pressure groups" consumer movements represent the general interestas as opposed to specific interests. See Bohets, Het land waarin wij werken, pp. I68-i 70 .

55. Hilton, Prosperity for All, p. 39. 


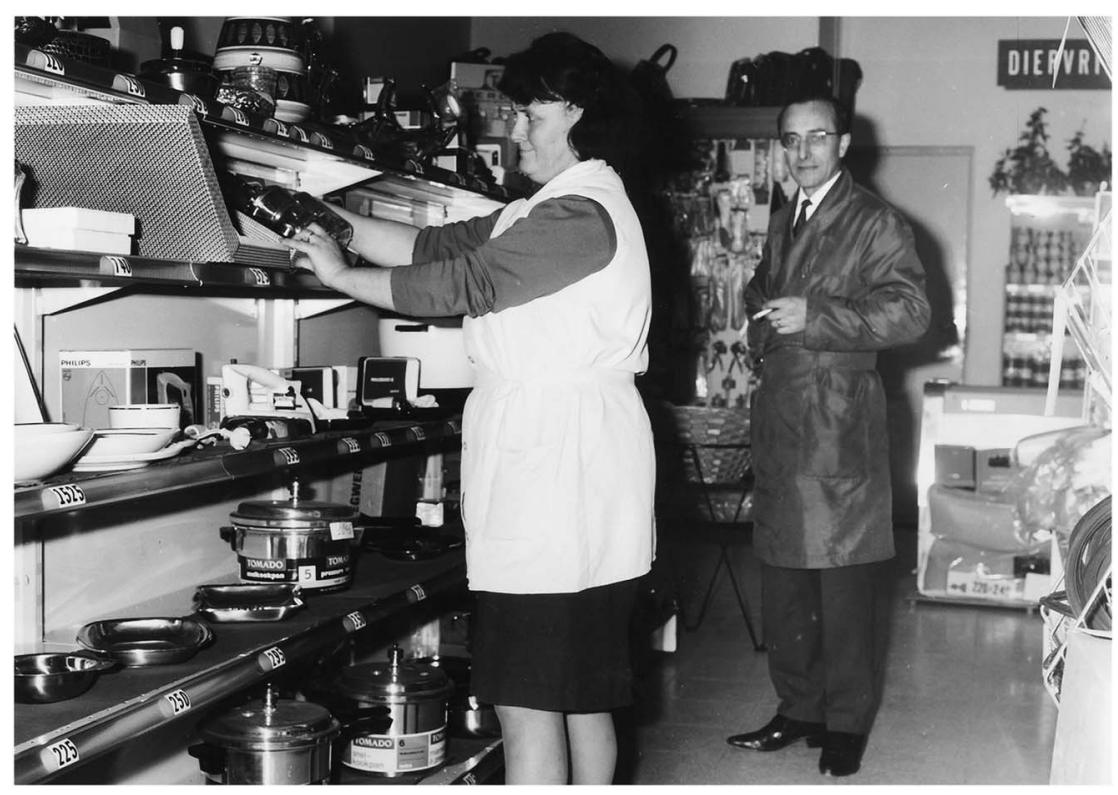

Figure 3. Cooperative store Geraardsbergen, 1950.

Amsab Institunt voor Sociale Geschiedenis.

\section{Message or framing}

The final and most important resource to analyse is the message delivered to the rank and file. Given the position of Darms and Castelain as part of the Catholic establishment, it is obvious that they framed the consumer interest from a different angle to the UFIDEC. TA showcased a more liberal, optimistic faith in the free market ("giving information") and scepticism towards a too powerful state. The UFIDEC consistently pressed for more government regulation and protection ("demanding defence"). The difference partly coincides with Gunnar Trumbull's categorization of consumerism. ${ }^{56}$ Just like consumerists in Germany, Britain, and Japan, TA pushed for an economic model of citizenship, with consumers as partners in the market economy, rather than collective actors in a politically regulated economic process. This was a novelty in a world where consumers were traditionally seen as political forces (either, following Trumbull's model, in a more direct "political" way or in a more mediated "associational" way).

The Belgian case, meanwhile, complicates Trumbull's analysis by engendering different varieties of consumerism coexisting at the same time.

56. Gunnar Trumbull, "National Varieties of Consumerism”, Jahrbuch für Wirtschaftsgeschichte, I (2006), pp. 77-93. 
This highlights the fact that these different models were not just logical outcomes, but could be simultaneous and contested realities. If the UFIDEC consistently used the Swedish regulatory framework as a worthy example to follow for Belgium, some of TA's early statements read like the deliberate, individualistic response of well-heeled consumers towards socialist encroachment. ${ }^{57}$ In 1960 , TA, for example, rejected a new public measure to manage collective water infrastructure, calling it a hidden form of taxation. They informed consumers how to dig their own private wells. Water consumers were told that, as long as others did not become ill from the water provided by such a well, the government could not object to this. ${ }^{58}$ In I963, the UFIDEC called for the establishment of a Ministry for Consumer Affairs. Ten years later, TA's management went to considerable lengths to prevent "consumers' interests being taken charge of collectively through a public institution". 59 It considered the projected Centre de Recherche et d'Information des Organisations de Consommateurs (CRIOC), a government-funded institution, a competitor. TA demanded that CRIOC not be allowed to communicate directly to the public. ${ }^{60}$

On many occasions TA appeared to take sides without doing so very explicitly. In the mid-I970s, at the height of renewed contention between labour and capital in Belgium, the edited volume on the Belgian economy, to which Van Rijckeghem contributed as president of TA, deplored any fundamental contestation of the market economy by trade unions and argued that consumer organizations could at least assist in the recovery of the market economy. Even during the I 980 s, TA's priority of attacking state monopolies placed it in the same corner as the employers' organizations. ${ }^{6 \mathrm{r}}$ This shows that TA could not avoid taking a political position and questions TA's most central claim of being strictly neutral and scientific.

TA's faith in technical knowledge as a superior form of knowledge was furthermore coupled with a conservative view on class and gender. Darms's political charter specifically addressed the young newly married man ("chef de famille"), who "wants to make a rational choice and has the mindset to understand the explanations that are given to him". ${ }^{2}$ Such technical explanations, the charter implied, were beyond the grasp of women who

57. While Belgium is a very explicit case of the competing coexistence of different consumerist organizations, the same constellations could also be found in other countries. See Kansas State University, Thomas Brooks Collection, Box I Administrative Files, folder 6, Research paper on "Consumer Problems in Europe" by Colston Warne for the 2nd Institute on Consumer Problems at the University of Minnesota.

58. Test-Achats, January and March 1966. See also Gert Vanwichelen, "Kritische doorlichting en evaluatie van de consumentenbeweging" (M.A. thesis, University of Leuven, 1987), p. 28.

59. Van Rijckeghem, L'Histoire de Test-Achats, p. I48.

60. Ibid., pp. I46-I 53 .

6r. Ibid., p. I36.

62. UGhent WVR, i i , Political charter of TA by Darms. 
supposedly could manage only the simplest of all purchases, namely food. In a 1966 TA feature called "The Diary of a Consumer", a male, unnamed author described how he and his wife went shopping for a new (and expensive) kitchen: "My wife, so distracted, so negligent, incapable of making an effort to listen attentively to the explanations, visits the showroom like a runaway horse. My personal intervention consists of limiting the money we will spend on expensive kitchen gadgets." ${ }^{33}$ When describing the working-class men who installed the kitchen, the author spoke of "one fat, pale supervisor and two youngsters with the haircut of the so-called Beatles and very little desire to tire themselves in the work". In short, TA's periodical also provided a funny outlet for the traditional paterfamilias, for whom the working class was a suspect group and who did not want to spoil his wife with too many kitchen aids. The discourse of TA corresponded to a reality: that of women lacking full authority over the marital bank account in particular and lacking professional legitimacy in general. This aspect assuredly played a role in the UFIDEC's decision to refuse a merger with TA. ${ }^{64}$ Indeed, the UFIDEC's whole endeavour was about valuing the work of working-class housewives and strengthening their expertise.

At the same time, the message broadcast by the UFIDEC had its own limitations. Its tone was often cautionary and repetitive, its main focus food. The UFIDEC's austere tone reflected the experience of poverty. This was not an attractive message to identify with, especially during the golden I960s. TA coupled tests of luxury products with a more optimistic, even entertaining, style. Its magazine was glossy; it was printed on thick paper and featured glamorous pictures. ${ }^{65}$ During the early i960s, TA paid about BEF 363,000 for printing fewer magazines than the UFIDEC, which paid only BEF 92,926 for its printing and editing. ${ }^{66}$ The UFIDEC used drawings of unhappy or angry consumers to illustrate its main argument: consumers were constantly exposed to structural injustices. The UFIDEC's periodical thus lost attractiveness over the years owing to its style and limited testing scope. In addition, several other processes contributed to a progressive crisis at the UFIDEC, which was, rather suddenly, discontinued in I984: one contributing factor was tensions between the women's organizations, the party leaders, and the management of the socialist cooperative movement, a male stronghold that did not take kindly to the internal

63. Test-Achats, January 1966.

64. See the following letter from Florence Mason, a CU colleague of Warne's, on Darms's traditionalism vis-à-vis women: Consumers' Union, New York, Colston Warne Papers, 27/5, letter from Mason to Warne, 7 March 1963. For the UFIDEC's objection to TA's implicit views of gender relations see Matton, "La défense des consommateurs", p. 98.

65. Van Rijckeghem, L'bistoire de Test-Achats, p. 23.

66. UGhent WVR, I I3, budget I962; and Amsab - Institute for Social History, Ghent, Archives of the Société Générale Coopérative, Compte du 31/12/1966. 
criticism that had been voiced by the women. Secondly, the socialist pillar itself was starting to run out of money and momentum. Thirdly, second-wave feminism repudiated the automatic connection between women and household consumption. The theme of conscious consumerism was taken over by the new social movements in a more fashionable way.

\section{BELGIAN TA AND THE INTERNATIONAL ORGANIZATION OF CONSUMERS' UNIONS}

As the haphazardly founded alliance between the American CU and Belgian TA became increasingly tight, the Belgians were able to insert their own ideas about what a "modern" consumer movement did. Darms, especially, was passionately opposed to lobbying government because he saw information as the only avenue for organized consumerism. Such a radical stance was new. In a 1956 paper, Warne had stated that the European example, and particularly the Scandinavian, was worthwhile considering for the American consumer movement because the Scandinavians were moving in another, but nevertheless effective, direction. The Scandinavians were negotiating with government and had public, as opposed to private, labelling schemes. ${ }^{67}$ The CU itself never shunned cooperation with the American trade unions and local governments. But in the context of Cold War "liberal internationalism" Warne's main concern was to separate what he considered the genuine consumerists from those initiatives dominated by groups that were not "bona fide". The IOCU's constitutional rules then reflected organized consumerism's identity construction as a movement that should and could divorce itself from politics. Formally, this meant that consumer unions were based preferably on the membership of individuals (like TA), rather than supported by other organizations (like the UFIDEC). The International Organization of Consumers' Unions (IOCU; today Consumers International) was founded in 1960 by five movements: the American CU, the British and Australian Consumers' Associations, the Dutch Consumentenbond, and Belgium's TA. ${ }^{68}$ Colston Warne secured \$10,000 from the CU to fund the IOCU. ${ }^{69}$ TA's authoritative position within this international initiative was an anomaly considering that they had just I,250 subscribers in 1960 and that the other partners were much better established. But the IOCU was the result of a series of informal consultations, rather than a reasoned procedure of selection and inclusion.

67. Kansas University, Consumer Movement Archives, Colston Warne (6/I), Proceedings of the 2nd Institute on Consumer Problems, I0-I I September 1956 (unpublished research paper), p. 22. 68. Hilton, Prosperity for All, p. 33.

69. Idem, "Americanisation, British Consumerism and the International Organisation of Consumers' Unions", in Kipping and Tiratsoo, Americanisation in 2oth Century Europe, pp. $25-60,26$. 
For instance, Warne had visited Darms in his apartment around August I959 and had mentioned his plans to launch an international consumer organization. When Warne had asked him about TA's rank and file, Darms had replied, without even batting an eyelid, that TA had I0,000 members. ${ }^{70}$ This was not true, but it assured TA of an influential position.

Although it seems a self-evident choice for a national consumer movement to join others under a US umbrella, in I 960 it was not. First of all, it was unclear what the newborn movements could gain from participating in the IOCU. The social-democratic UFIDEC, for instance, was more interested in the possibilities of the Bureau Européen des Unions de Consommateurs (BEUC) at the beginning of the I960s. For this, they even cooperated with their competitor TA and others. They saw the BEUC as a tool to influence European legislation and jointly perform tests on the common market, which had brands and sensitivities different from the Australian or North American consumer markets. Richely, the UFIDEC's spokesman, furthermore believed that it was too early to join the IOCU: establishing a sizeable consumer movement came first, international cooperation second. ${ }^{7 r}$

Because the UFIDEC was the sum of two different women's movements with varying concerns (namely the co-operative cause and health matters), its female leaders were often not disposed to taking up an (expensive) international engagement. The Women's Cooperative Guild fostered international connections of its own, but these dealt mostly with cooperative practices in Europe. ${ }^{72}$ A second reservation contemplated by Richely and some of the Scandinavian public-sponsored movements was the cost of membership, which was quite high, thus implying a transfer of financial means from a national consumer movement (often publicly or labourmovement funded) to a private association with little accountability. ${ }^{73}$ Finally, consumer activists such as the Belgian Jacques Neirynck of TA and the African-American Florence Rice expressed doubts about the IOCU as a tool that could have real results for consumers. Rice stated in 1970 that "[the IOCU gathering] was just another nice meeting that amounted to very little: you hear the same old platitudes and life just goes on as before" ${ }^{74}$

70. Van Rijckeghem, L'Histoire de Test-Achats, p. 26.

7I. Institut Emile Vandervelden, Brussels, Archives Jeanne Vanderveken, Rapport sur UFIDEC 1962, p. 10.

72. See, for instance, Amsab, Coop, i is (files concerning study trips), International Cooperative Women's Meeting, Innsbruck, June 1956.

73. To reduce the costs of international membership fees, movements over the years proceeded to establish separate, commercial editing branches to avoid the entire budget being taken into account by the IOCU, which demanded a percentage of the total budget of its members. On the need for such "outsourcing” see, for instance, UGhent, WVR, 2, Board Meeting, 4 June 1974, and "Aanvraagprocedure Fédération Romande des consommatrices", is March 1973.

74. Rice is quoted in the New York Times, 4 July 1970, "Consumers' Unions Optimistic as 30 Nation Talks End”. See also interview with Jacques Neirynck by the author, I 3 September 2014. 
The press described the 1970 IOCU meeting in Vienna as a semi-recreational event for professional cheapskates. ${ }^{75}$ Strengthening advocacy networks was one thing, but to what end were these networks used?

The IOCU was granted a category III (observer) status on the United Nations Economic and Social Council (ECOSOC) in 1963, upgraded to a category II in 1969 , and finally to category I in $1977 .{ }^{76}$ Hilton has attributed the IOCU's relatively rapid legitimacy to its respectable free-market-based activism. ${ }^{77}$ Still, even the legitimacy and expertise of professional testing proved insufficient to allow it to participate on an equal footing with business in this realm of supranational organizations. After the technical hearings of the UN commission for food standards, for instance, one frustrated IOCU representative claimed that "consumer interest received only lip service". ${ }^{78}$ Moreover, at an individual level, the driving figures within the IOCU had very different motives for devoting their lives to the international consumer movement. When looking at Florence Mason or Persia Campbell, the two American women who almost singlehandedly took on the job of corresponding with embryonic consumer movements worldwide or taking up UN representation, a strong idealism stands out. ${ }^{79}$ But Mason, Campbell, and Warne teamed up with European consumer leaders who were much less interested in building this kind of consumer internationalism and far more concerned with the practicalities of testing. The American lawyer Rhoda Karpatkin was the IOCU's president between 1984 and I99I. Looking back, she remembers: "The consumer organization world that I entered [...]; the power and the leadership was all male $[\ldots]$ the question for IOCU became whether it was a sort of collegial testing institution or whether it had a role in activism [...]. It was really a clash." 80

It was not as if the IOCU consciously ignored government regulation or focused only on the issues of affluent consumers. On the contrary, very early in its history the IOCU expressed the ambition to go beyond that. ${ }^{81}$

75. New York Times, 2 July 1970: "[P]ossibly the chief complaint is the price of coffee. 'Forty cents for a cup of coffee is too steep', Dr. Colston Warne grumbled as the delegates boarded busses for a sightseeing trip to Vienna."

76. The advancement is detailed in Consumers' Union, New York, Colston Warne Papers, 33/6, Wilner to Sai, 2 I February 1977.

77. Hilton, Prosperity for All, pp. II-I 5, 93, IоI-I 16, and idem, "Americanisation, British Consumerism", p. 28.

78. UGhent WVR, 5, IOCU stencilled progress report I968-i 970, p. 5.

79. Mason wrote to Warne that representing consumers was the "morally" right thing to do. See Consumers' Union, New York, Colston Warne Papers, 28/3, letter from Mason to Warne, 2 I January 1966.

80. Interview with Rhoda Karpatkin by the author, 6 February 2015 .

8 I. See, for example, UGhent WVR, 5, interview with development economist Jan Tinbergen by Willy Van Rijckeghem for the International Consumer (1970). 
But for many years, IOCU statements had little bearing on reality. The IOCU's core infrastructure consisted of a network of around seven highly motivated academics and experts and a secretariat of two in The Hague. The organization thus depended on the ambitions of its cooperating members. Looking at the trajectory of these individual member organizations, and of the Belgians in particular, thus helps to put this case of NGO practice and international advocacy into perspective.

\section{MARGINALIZING PUBLIC CONSUMER DEFENCE MODELS IN THE IOCU}

In I965, Warne stated that the IOCU should function as "a clearing house and an international centre to authenticate and to assist genuine consumer efforts" ${ }^{82}$ In this pragmatic, self-directed orientation, TA’s most consistent contribution was its active defence of private-based testing movements at the expense of public or "partisan" institutions. It was able to exert considerable influence in this regard because of its prominent position on the IOCU's executive board and its resistance to the election of new members. The highest level of IOCU decision-making was thus dominated by the male leaders of the affluent West, who held the so-called Anglo-Saxon model in high regard, i.e. the preference for private-based, "information-oriented" consumer advocacy. Members investigating new candidates for the IOCU attached much importance to whether a movement was supported by individual members or by organizations. The former was preferred over the latter, and the IOCU only loosened its stance after meeting the realities on the ground in developing countries. ${ }^{83}$ However, if needed, the rules were bent somewhat, and while new members had to abide strictly there was leniency for the founding organizations. For example, TA never really complied with rule number 6 , which stated that consumer movements should be democratically accountable to their consumer members. ${ }^{8}$

In 1964 the Norwegian, Danish, and Swedish consumer councils, which could pride themselves on the widest dissemination of consumer magazines in the population and the most elaborate mechanisms for consumer protection, demanded changes. The final compromise, brokered by Colston Warne, formally abolished the membership categorization of private versus public consumer organizations. This did not entirely please the Belgian Willy Van Rijckeghem, who was more ardent than the Americans on this

82. Quoted from "Consumer Unions Warned of Fraud: World Parley in Oslo Told of Bogus Testing Groups", New York Times, 23 June 1964. The emphasis is mine.

83. See, for example, the first drafts of the guidelines; Consumers' Union, New York, Colston Warne Papers, Instructions on financing a consumer organization (undated).

84. Van Rijckeghem, L'histoire de Test-Achats, p. 37. 


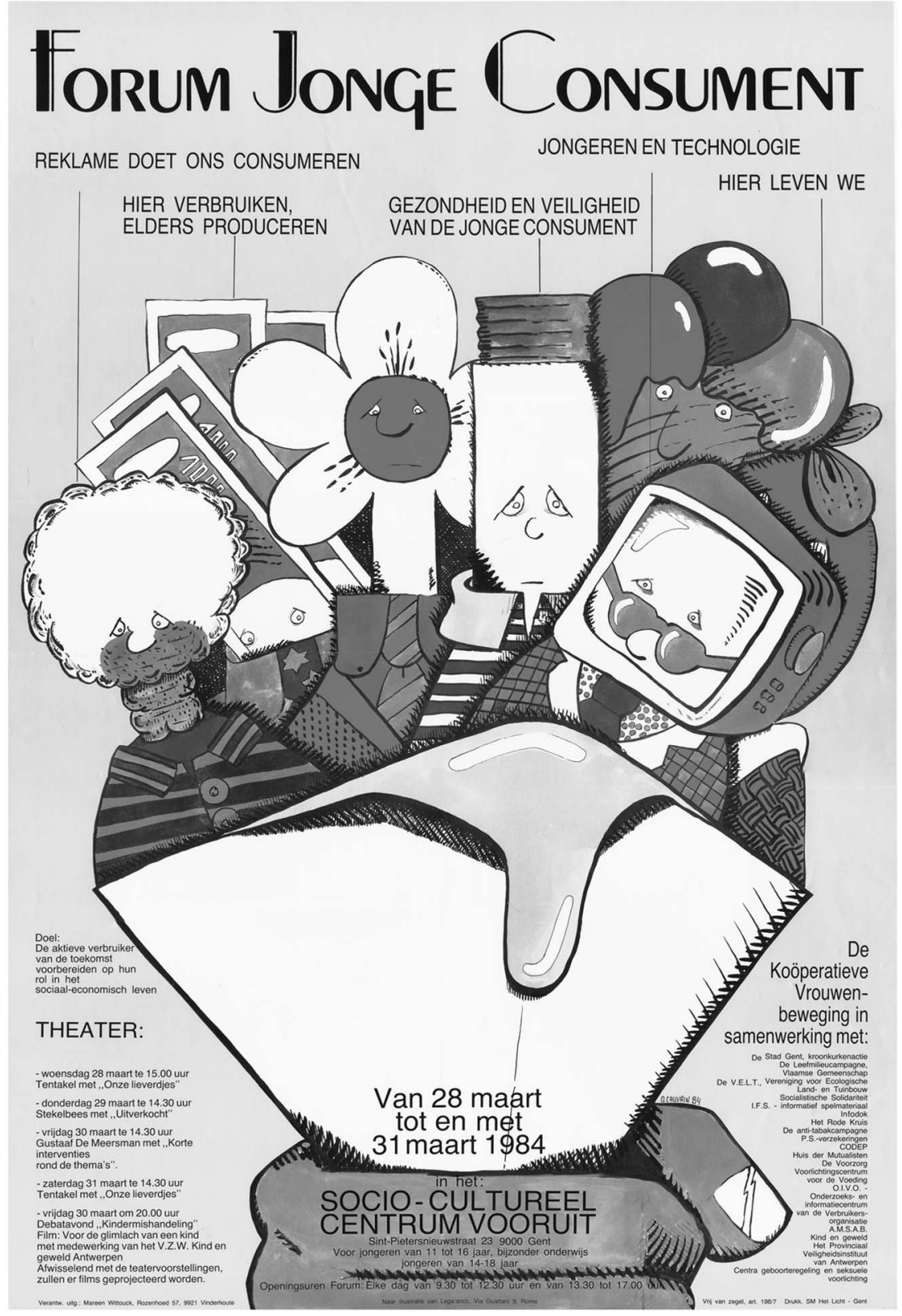

Figure 4. Meeting for the young consumer 1984: a poster for an educational consumer event organized by the social-democratic women.

Amsab Institunt voor Sociale Geschiedenis. 
matter. ${ }^{85}$ Yet, a new complicated system of multi-level membership and separate meetings of the founding organizations ensured that, in practice, the strings were still pulled by them or their approved favourites. ${ }^{86}$ While Matthew Hilton claims that the "division between the pure and the tarnished" was quickly abandoned after i968, Van Rijckeghem's memoires on the I970s are impregnated with exactly this concern to have public organizations subordinated or excluded. By 1975, when he was elected president of the IOCU for three years, he wrote: "[I]t escaped no one's notice that the 'official' organizations were no longer represented on the executive board." ${ }^{87}$ The Swedes had already quit the IOCU in 1972 because public funding no longer permitted them to pay the IOCU's membership fee. ${ }^{88}$ The decision was thus not taken by the IOCU itself, even if Warne wrote to Van Rijckeghem in 1970 that he envisaged the removal of Swedish consumer advocate Ursulah Wahlberg from the IOCU as a long-term solution to "the Scandinavian desire for change in IOCU's constitution". ${ }^{89}$

The French National Institute for Consumption (INC) was another telling example. The INC was excluded from the IOCU to the benefit of the Union Français des Consommateurs (UFC), which by that time had become TA's commercial partner..$^{90}$ In fact, the partnership was forged just because the UFC's commercial survival was threatened. TA's leading figures were highly instrumental in casting doubt upon the credibility of the INC to the Americans. But Hans Thorelli, an American academic who studied the consumer movement, wrote to Warne that this bickering between the INC and the UFC was "typical of the French" and did not really reflect any inferiority on the part of the INC. ${ }^{9 \mathrm{I}}$ Rather than proving that public institutions could not defend the consumer interest, the Belgians were a priori questioning their capacity to do so. The importance of upholding a rigid separation between consumer activism and politics or between the private, pure model and the public, tarnished one was not

85. Van Rijckeghem's urge to separate the "political" and "the consumer interest" is legendary. See, for example, the issue of a possible fusion between the BEUC and the IOCU, which arose in the I970s and which he most decidedly disapproved of; UGhent WVR, I03, letter from Goldman of the Consumers' Association to Roberts, I7 October 1975 .

86. UGhent WVR, 5, IOCU Executive Meeting, 2 August 1972; UGhent WVR, 4, IOCU Executive Meeting, 2 November 1973 ("financial and constitutional changes").

87. Hilton, Prosperity for All, p. I06, and Van Rijckeghem, L'Histoire de Test-Achats, p. I I I.

88. Hilton, Prosperity for All, pp. 39, 60, and Van Rijckeghem, L'Histoire de Test-Achats, p. Io8. 89. UGhent WVR, 5, letter from Colston Warne to Van Rijckeghem, i I May I 970.

90. Van Rijckeghem, L'Histoire de Test-Achats, pp. 64-65; Consumers' Union, New York, Colston Warne Papers, 30/6, letter from Van Rijckeghem to Warne, io October I 97 I.

91. Consumers' Union, New York, Colston Warne Papers, I6/9, correspondence Warne and Hans Thorelli. By I975, the INC could no longer pay the cost of membership. See UGhent, WVR, I, Letter from Estingoy to Van Veen, 28 October 1974; UGhent, WVR, 4, Statement before IOCU executive, concerning application of INC (n.d.). 
explicitly addressed by Van Rijckeghem - indicating that it had become something of an axiom. Questioned in an interview, he has emphasized that the consumer cause could be subordinated to national (industrial) interests in public institutions, while independent movements are shielded from these pressures..$^{92}$

A neo-classical economic conception of markets and politics as two separate worlds is obviously present here. Conviction had as much to do with this stance as empirical assessment. ${ }^{93}$ But whatever the intellectual plausibility of these convictions, Van Rijckeghem had to confront much more ambiguous and intricate realities in the consumer world than implied by his paradigm. First of all, Van Rijckeghem knew that even the "independent" private comparative testing organizations were vulnerable to all kinds of influences. The Italian private comparative testing organization turned out to be seriously corrupt in 1975 , and doubts were also cast in relation to the conduct of the director of a private Japanese organization. TA preferred to keep these troubles out of the limelight in the official statements issued by the BEUC and the IOCU. ${ }^{94}$ On the other hand, there was good evidence for the effectiveness of the public model. By 1972, Sweden had become a pioneer in consumer protection, not least because of its comprehensive product-labelling system of 1957. Yet by 1968, Louis Darms was still advocating a system that was not "too rigorous", in which products had both a "tag of truth" for the consumers and an "arty tag" for the pleasure of the advertisers. ${ }^{95}$ Sweden could furthermore boast its pioneering use of the consumer ombudsman (introduced in I97I), who helped negotiate binding agreements between consumers and other economic stakeholders. The ombudsman could even initiate lawsuits in a special court. By 1972 Sweden effectively had a high-ranking agency for consumer policies. ${ }^{96}$

Another reality that undermined the principles promoted by TA was the fact that it had not repudiated the possibility of government funding during its early, financially difficult years. When the private channels of funding

92. Interview with Willy Van Rijckeghem, I7 June 20I4, and Jacques Neirynck, I3 September 2014, by the author; UGhent WVR, 44, interview with Castelain by Blavier (1999), passim.

93. Correspondence between Van Rijckeghem and the economist Scott Maynes of the CU reveals how, in the "struggle between interventionalists (or Naderites) and information-minded activists" within the consumer movement, these two economists favoured the latter group; UGhent WVR, 92, Van Rijckeghem to Maynes, I 3 April 1977.

94. UGhent WVR, 2, Meeting of the Executive Council of Test-Achats, 4 May 1974, and UGhent WVR, 39, letter from law firm Karpatkin, Ohrenstein, and Karpatkin to Warne, 9 February 1972. 95. UGhent WVR, i 8 , Board Meeting, io May 1968. Darms stated: "[O]ne might give preference to a side-by-side of two labels, one objective, the other one independent, advertising, idealist, artistic, poetic, aesthetic, suggestive and seductive."

96. Consumer Policy in the Baltic and Nordic Countries: Report from the Nordic-Baltic Consumer Conference in Pärnu, May I0-I5, I992 (Copenhagen, I993), pp. 8 and 5I-59. 
appeared uncertain in I96I, TA lobbied to obtain BEF I million from public funds. In this attempt, Darms's connections with officials at the Ministry of Economic Affairs were pivotal. But the plan failed, and TA was forced to continue independently. ${ }^{97}$ This turned out to be a blessing, as Colston Warne and the IOCU had officially proclaimed in 1960 that consumer movements could not depend upon government funding but had to be built upon individual membership and magazine sales. ${ }^{98}$ In a way, TA - which would later become one of the most ardent standard-bearers of the private, non-political, non-activist principle - came to fit these standards by a rather contingent constellation.

Finally, those committed to this model seemed unable to acknowledge that the Anglo-Saxon commercial model stemmed from a particular context that was not readily replicable in other settings. The CU could develop because it initially had financial support from liberal foundations (such as the Elmhurst Foundation), because there were favourable tax rules, and because the United States offered a vast, unified market for sales and a monolingual public sphere. The situation was very different in Europe. Moreover, in the case of Belgium's TA, the commercial drive that is inherent to private-based testing organizations curbed broader civil society coalitions that might have strengthened consumer defence. Similar organizations thus became competitors in a limited market, rather than potential allies.

Whereas the IOCU lacked funding to actively disseminate the "nonaligned" commercial model abroad, TA intentionally expanded beyond the Belgian frontiers. Especially after the first difficult decade, the Belgians became the driving force behind a consumers' multinational. After overcoming the financial difficulties of the early i960s, TA used its profits as capital to invest in weaker private testing organizations such as those in France (1968-1973 and again after I995), Spain (since 1987), Italy (since 1989), and Portugal (since 1990). This was both a strategy for survival or accumulation, and a political choice: in at least two cases, TA's intervention was expressly directed against a public institute for consumer interest. Looking back on the Spanish case, one of TA's leaders put forward the view that "the social-democratic party has spent years leading a consumer organization from behind the scenes". ${ }^{99}$ While this claim was questionable as such, it also reflected TA's distrust of the labour movement and the legitimacy of organized labour as consumerists.

97. UGhent WVR, I I4, Board Meetings, is November 196I, i 2 December I96i, and 26 May I96I.

98. Van Rijckeghem, L'bistoire de Test-Achats, p. 37.

99. Interview with Armand De Wash, in Trends: Financieel-economisch magazine, 7 November 1996. Willy Van Rijckeghem reacted with some surprise to De Wash's claims, which he considered not entirely correct; interview with Willy Van Rijckeghem by the author, 26 June 20 I 5 . 
In the European Mediterranean, TA effectively became the only transnational consumer group within the European Union. Much of TA's international success was built on the personal enthusiasm of its movement entrepreneurs. Willy Van Rijckeghem was able to combine active membership of the IOCU executive with his work as an academic. He tracked and stimulated consumerism from Iran to Zaire and Jamaica, often as a visiting scholar. ${ }^{100}$ Van Rijckeghem's energetic efforts on behalf of the private model sometimes clashed with socio-economic realities, especially in poorer countries. In 1977 , he admitted:

I will not easily forget the answer I got from a Moroccan lady a few years ago, when I tried to convince her to start a consumer organization in her country. She said: "Yes, this would be an excellent idea to help the foreigners who live here and who do not know how to spend their money. We however, have no such problem, because we have no money." "or

TA's investments make it even harder to sustain the label of complete political neutrality. At a 1987 board meeting, TA decided to invest BEF I.5 million annually in the Argentinian consumer movement Adelco. This was only a few years after the fall of the dictatorship and Adelco was an offshoot of a rather small conservative party, counterbalanced in its proposals mostly by labour-movement organizations. ${ }^{102}$ TA sent Castelain to Argentina to make sure the investment paid off. The board stated that they would judge Adelco only on its consumerist dimensions, meaning that no account would be taken of Adelco's political ideology. TA nonetheless urged Adelco to adopt a more technocratic approach. ${ }^{\circ 03}$ However, in an appendix it was stated more clearly that support for Adelco was a counterforce against "a whole series of radicalized and political groups that might otherwise dominate the consumerist scene". ${ }^{104}$ Deciding to sponsor Adelco and not the consumer interest groups associated with the left was a conscious form of intervention.

TA's recipes for non-political interest representation were not uncontested. Staff members often questioned whether TA should pursue or at least clarify its political goals with more transparency, and so did their foreign partners. In France, TA's commercial connoisseurship enabled the French UFC to grow from about 5,000 subscribers to 240,000 subscribers in 5 years. But when the UFC gave more voice to its local consumer clubs in I974, these stood up to TA as a stakeholder because they did not agree with

I00. See the range of his activities alluded to in UGhent WVR, 40, letter from Goldman to Warne, 3 April 1970.

I0I. UGhent WVR, 9I, Mediterranean Consumer Conference, Athens, 28-30 March 1977.

102. Sybil Rhodes, Social Movements and Free-market Capitalism in Latin America: Telecommunications Privatization and the Rise of Consumer Protest (New York, 2006), p. 73.

I03. UGhent WVR, 6i and 64, Board Meeting, I4 July 1987.

I04. UGhent WVR, 6I and 64, Board Meeting, I 4 July 1987, appendix. 
the Belgian recipes, which were deemed too "commercial". Consumer activism in France was much more grassroots and more firmly linked to trade unions. ${ }^{105}$ Consequently, the local consumer clubs and the UFC began bringing producers to trial, pressuring public authorities, and even initiating "consumer strikes". The more activist local consumer clubs saw their membership triple within a year and a half.

Similar developments could be observed in Argentina and Brazil during the i990s. In Argentina, several energetic lawyers wanted to steer Adelco away from individual service provision and towards consumer protection. This created tensions with the Belgians and, eventually, the end of funding. ${ }^{106}$ In the case of the Brazilian Instituto Brasileiro de Defesa do Consumidor (IDEC), the local board wanted an ethical charter for the promotion of the magazine, which TA considered an attempt to "ideologically control marketing, which is not acceptable for us". ${ }^{107}$ In $200 \mathrm{I}$ Van Rijckeghem founded Pro-Teste, a new Brazilian consumer organization. Since then, the two have coexisted, although somewhat uneasily. ${ }^{108}$ The IDEC describes its goals in the following vein: "to contribute to a fair marketplace; to enforce and enhance consumer legislation; to promote consumer welfare [...] and, more generally, to further the goals of democracy by stimulating citizen awareness and participation". Meanwhile, Pro-Teste's mission statement stresses that it is a "non-profit and non-party political organization, independent of government and companies, which vows to strengthen purchasing power and awareness through comparative tests, and to provide services to consumers". ${ }^{109}$

\section{AGENDA-SETTING AND THE MALLEABILITY OF THE IOCU}

As in the case of other organizations, there was a lot of learning-by-doing involved in the development of the IOCU. Its initial agenda setting was receptive to the dominant ideas of the age. If the main difference in orientation among consumer movements was, as Hilton put it, between "access" and "choice", then the European founding members of the IOCU initially emphasized "choice". Those financing the IOCU undertaking in the early i960s tended to defend the rational buyer in the marketplace,

I05. See, for instance, Gunnar Trumbull, "Strategies of Consumer-Group Mobilization: France and Germany in the 1970s", in Daunton and Hilton, The Politics of Consumption, pp. 261-282, and, for the French situation, Steiff, "L'information comme mode d'action", pp. 103-106.

106. Rhodes, Social Movements and Free-market Capitalism, p. 84; UGhent WVR, 68, Board Meeting Conseur, 2 September 1996.

107. UGhent WVR, 69, Board Meeting Conseur, I4 December 1996.

I08. Interview with Van Rijckeghem by the author, 26 June 2015 .

I09. Member profile IDEC and member profile Pro-Teste, http://www.consumersinternational.

org/our-members/member-directory/, last accessed 28 May 20 I 5 . 
rather than the individual or community that could ill afford to buy on this market or question its limits. The IOCU's 1962 Brussels Manifesto on organized consumerism emphasized constructing global free markets, but without foreseeing its challenges. ${ }^{\mathrm{IO}}$ Moreover, it was assumed that the organized consumerism of the Global North (based on sales of product tests, high literacy, and rising incomes) could easily be transferred to developing countries. Starting from these paradigms, it seems the IOCU's work had little disruptive potential. The IOCU's Guidelines for Consumer Protection, which were proclaimed by the UN in 1985 after ten years of costly struggle, were described by Hilton as "the lowest common denominator of regulation". "II But as more activist and contentious forms of consumerism emerged within the IOCU during the mid-r980s, organized consumerism seemed to gather greater momentum than the business community could allow. Even the modest activities of the IOCU thus turned it into a target for neo-liberal campaigners.

In the framework of development work, the IOCU had set up a regional office in Penang, Malaysia. Coming from this Malaysian office, the young lawyer Anwar Fazal was pivotal in steering the IOCU in new, more combative directions. He succeeded Willy Van Rijckeghem and became the IOCU's first remunerated president in 1974. Corporate crime in the developing world had taken on such dimensions that new approaches, beyond information, were needed. During the early i 980 s, Fazal helped to launch the International Baby Food Action Network (IBFAN, I979), the Health Action Network (198I), and the Pesticides Action Network (PAN, I982). He also opened the door to more intense cooperation with labour movements. ${ }^{\mathrm{II} 2}$ Eventually, this led to discontent because the IOCU's financing members from affluent countries disliked Fazal's "radicalism". Again, the dilemma of whether to be a social movement or just a publishing company came to the fore. The sensitivity of the matter is illustrated by Van Rijckeghem's claim that "especially the Americans wanted Fazal out”, while the American successor to Fazal said that it was the European movements that were less inclined to support him. ${ }^{\mathrm{I} 3}$

After 1985 the IOCU disassociated itself from the networks and returned to a more familiar agenda. Fazal left under acrimonious circumstances. ${ }^{\mathrm{I} 4}$

I Io. The Brussels Manifesto was communicated to the press too. See Van Rijckeghem, L'Histoire de Test-Achats, p. 39; and Test-Achats, April 1962.

I I I. Hilton, Prosperity for All, p. I 2 I.

I I 2. UGhent WVR, I09, Conclusions and recommendations of the IOCU education committee, I980.

I I3. Interview with Willy Van Rijckeghem by the author, I7 June 20I4, and interview with Rhoda Karpatkin by the author, 6 February 2015 .

I 14. Hilton, Prosperity for All, pp. I08, I3 I, I48; idem, "The Death of a Consumer Society", Transactions of the Royal Historical Society, I 8 (2008), pp. 2 I I-236, 224-228. 
That Third-World debt - incurred by governments without consumers/ taxpayers having a say in it - was never an issue within the IOCU led Fazal to claim that "the consumer movement marginalizes itself by dealing with little problems". IIs Around the same time, consumer activist Ralph Nader was fighting for a powerful Consumer Protection Agency in the USA along the lines of the Scandinavian model. His proposal was defeated by a massive mobilization of corporate interests through so-called political action committees (one of the major institutions for electoral lobbying in the USA). Both Nader and the IOCU were heavily attacked in the media. Backed by the Reagan administration, anti-regulatory actors such as the Heritage Foundation and the American Enterprise Institute made sure that the IOCU's proposal for a code of conduct for transnational corporations never stood a chance. Meanwhile, UN institutions were bypassed by the Uruguay Round, which culminated in the founding of the World Trade Organization (1995). The IOCU's subsequent decision principally to support the free trade agenda in exchange for a seat at the talks (while most NGOs were protesting outside) was described by Matthew Hilton as a less than successful strategy. ${ }^{116}$

However, neo-liberal accents within the IOCU were the result not only of external pressures. The IOCU showed a certain malleability even before I995. Much of this was related to the commercialized model of organized consumerism, which could not easily allow for non-profitable activities. In I 975 the IOCU decided to abandon its legal and social committee. From then on, legal work for the consumer was to be done on an ad hoc basis. The committees on testing procedures were retained, however. ${ }^{17}$ It seemed a prelude to a more general, deregulatory climate.

The IOCU's I975 congress on the problems of inflation, organized by Willy Van Rijckeghem, is another example of an agenda that could be appropriated by any number of other interest groups. ${ }^{118}$ The congress described inflation as a symptom of an international plague, demanding international diagnosis, prescription, and cure. According to Van Rijckeghem, consumers lost all sense of price levels under conditions of inflation, which would hamper the workings of the market. ${ }^{119}$ While the choice of inflation as a main concern might have reflected a general openness to the

I15. Quoted in Ellen Hosmer, “A Consuming Interest", Multinational Monitor, 9 (I988), available at http://www.multinationalmonitor.org/hyper/issues/r988/0I/mmor 88 _05.html, last accessed 20 May 2014.

I 16. Hilton, "The Death of a Consumer Society", pp. 229-232; Lizabeth Cohen, "Is It Time for Another Round of Consumer Protection? The Lessons of Twentieth-Century US History", The Journal of Consumer Affairs, 44 (2010), pp. 234-246.

I I7. UGhent WVR, I02, Executive annual report IOCU, I975.

i 18 . UGhent WVR, 20, IOCU conference i975.

I 19. Van Rijckeghem, L'Histoire de Test-Achats, pp. го7-г 30. 
impending crisis, there was actually very little that comparative testers could offer on the topic. One approach could have been to emphasize the role of monopolistic producers driving up prices in an unwarranted way, yet Van Rijckeghem did not believe consumers could win that fight. ${ }^{{ }^{20}}$ Surveys in TA instead targeted individual customers and urged them to keep track of their expenses. In connection with Van Rijckeghem's ideas on wage policy in Belgium, the prioritization of inflation becomes even more significant. Invited to an academic seminar on purchasing power in I980, Van Rijckeghem stated that increases in productivity should not necessarily lead to higher wages for some workers, but rather to lower prices for all consumers. ${ }^{\mathrm{I} I}$

There is no space here to discuss the complex causes of inflation, its incidence in the I970s, and its effects on different social groups. Suffice it to say that inflation was consciously recast and re-narrated in the I970s and I 980 s to fit neo-liberal tenets such as monetarism, critiques of big government, supply-side tax theory, and stabilization policy. ${ }^{122}$ The debates surrounding inflation illustrate how, under the rubric of neutral consumer representation, the currency of a specific political project could be potentially reinforced - even if this project was not actively supported by the IOCU. In this way, consumer movements were at the same time contesting and reproducing global corporate capitalism.

\section{CONCLUSION}

This article set out to compare the social-democratic association UFIDEC and the private, commercialized TA (which treasured its own political linkages), the two main postwar consumer movements in Belgium, the way in which they defined the consumer interest, and their entanglement with the international scene. Analysing these two organizations in terms of social movements and resource mobilizations revealed a series of differences that were by no means coincidental. While Matthew Hilton has titled his study of organized consumerism as the search for a social movement, the Belgian case suggests that one could appropriately speak of the struggle for begemony over a social movement. Each of the different comparative testing movements had specific origins that determined its repertoire of collective action. While all consumer movements spoke of protection from

I 20. Bohets, Het land waarin wij werken, p. 63.

I 2 I. See Van Rijckeghem's publications of the time: Geoffrey Maynard and Willy Van Rijckeghem, A World of Inflation (New York, 1976); Willy Van Rijckeghem, "Veranderingen in de situatie van de consument”, in Juul Hannes (ed.), Consumptiepatronen en prïsindices (Brussels, 1981), pp. 96-97; Roland Beauvois, Willy Van Rijckeghem, and Robert Leroy (eds), Le chômage. Interpretation et stratégie face à la crise (Brussels, 1978).

I22. Mark Blyth, Great Transformations: Economic Ideas and Institutional Change in the Twentieth Century (New York, 2002), ch. 6. 
the excesses of the market, only some were willing to do this in an overtly political way.

The principal choice to be taken by each movement was between targeting the demand side through education or controlling the supply side through legislation. Within the framework of embedded liberalism, consumers rather than producers were made responsible for the management of a "good" mass consumer society. The competition between the UFIDEC and TA in the national field mirrored a bitter global renegotiation over the nature of organized consumerism and the extent to which it was to be considered "political". Both in resources and inspiration, the middle-class-oriented variety of consumerism was different from the labour-movement-related variety. While the former was upheld as the future, the latter was subtly marginalized, for example through the IOCU's institutional designs and the deliberate promotion of supposedly neutral "technocratic" movements. Whether this process should be framed as Americanization, as embourgeoisement, or as "grobalization" ${ }^{123}$ remains a matter of interpretation. But the fact remains that under the banner of modernization it was no longer uncommon for social movements to make themselves dependent upon the very market they sought to reform.

Social historians dealing with the postwar mass consumer society face the challenge of its global dimensions. Studying the Belgian consumer movements and their international insertion points to a series of directions. First, as has often been asserted in global history debates, the global and the local should not be treated as neatly separated realms; both are relevant to understanding how hegemony and power are constituted. Second, international movements need to be researched from a historical perspective that is sensitive to class and gender. In relation to that a systematic comparison of the IOCU and the International Cooperative Alliance (the international association of cooperative organizations) would be worthwhile and might yield some surprises. Although these two international organizations had very different "constituencies", both spoke on behalf of consumers. Third, while class is a fundamental category for understanding consumerism both at the local and international levels, the development of consumerism demands openness to the intersectionality of class with other social cleavages: white-collar and blue-collar workers, men and women, more and less educated, the expertise of the exact sciences versus that of the social sciences and humanities, and, last but not least, the

I23. Grobalization (a neologism derived from "growth" and "globalization") is defined by George Ritzer as "the imperialistic ambitions of nations, corporations, and organizations, [...] and their desire - indeed need - to impose themselves on various geographic areas [...] [while] their main interest is in seeing their power, influence and [sometimes] profits grow". See Georges Ritzer, "Rethinking Globalization: Glocalization/Grobalization and Something/Nothing", Sociological Theory, 2I (2003), pp. 193-209, 194. 
difference between generations. As this study indicates, these were as powerful at the level of supranational organizations as they were in local Alltagsgeschichte.

Finally, the interpenetration of the neo-liberal project and civil society organizations is ominous. It questions the idea that neo-liberalism is an exclusively external process emanating only from one sector of society. ${ }^{\mathrm{I} 4}$ Movements of consumer advocacy were linked in a complex and sometimes contradictory way to broader processes of change. While they could work in many ways, they cannot be reduced to mere technical or to politically neutral movements. The rise of neo-liberalism appears as a construct of hegemonic ideas, shared among experts, policymakers, and to some extent ordinary people. While working for the individual in the marketplace, consumer movements could become allies in the quest to frame the entire public debate in narrow budgetary terms. The ease with which these ideas were then translated into policy practice merit our full attention.

\author{
TRANSLATED ABSTRACTS \\ FRENCH - GERMAN - SPANISH
}

Giselle Nath. Reproduire ou contester le global? Le consumérisme organisé en Belgique et ses imbrications internationales (1957-1995).

De 1957 à 1984, les consommateurs belges furent représentés par deux organisations comparatives de tests: Test-Achats et l'Union Féminine pour l'Information et la Défense du Consommateur. Ces deux organisations de consommateurs divergèrent fondamentalement par leur personnel, leur public et leur encadrement idéologique des intérêts des consommateurs. Seule Test-Achats, "politiquement indépendante", s'affilia à l'Organisation Internationale de l'Union des Consommateurs (IOCU), même si elle fut au départ plus petit et plus faible que l'Union Féminine, alternative socio-démocrate pour les consommateurs. Une analyse comparative du consumérisme organisé en Belgique révèle comment, après I 957 , l'intérêt des consommateurs fut progressivement reformulé pour correspondre à une définition hégémonique. Un modèle privé et commercial de la représentation des consommateurs fut activement promu envers et contre un dialogue transatlantique complexe. En outre, je soutiens que les liens internationaux - ou le manque de ceux-ci - des deux organisations sont essentiels pour expliquer leur succès (ou leur échec). La diffusion du consumérisme organisé pendant les années 1950 et 1960 se rattacha financièrement et idéologiquement au cadre de régulation keynésien- fordiste. L’attaque du libéralisme intégré à la fin des années 1970

I24. This does not invalidate interpretations of "neo-liberalism" as a coherent class project. See David Harvey, "Neoliberalism as Creative Destruction", Annals of the American Academy of Political and Social Science, 610 (2007), pp. 22-44. 
posa donc de graves défis. La modélisation des choix et des parcours des consommateurs activistes belges dans un contexte international nous permet de mieux comprendre ces défis.

Traduction: Christine Plard

Giselle Nath. Reproduktion oder Anfechtung des Globalen? Die Verbraucherbewegung in Belgien und ibre internationalen Verflechtungen (1957-1995).

Zwischen 1957 und 1984 wurden belgische Verbraucher von zwei produktvergleichenden Organisationen vertreten: Test-Achats und der Union Féminine pour l'Information et la Défense du Consommateur. Diese beiden Verbraucherorganisationen unterschieden sich grundlegend hinsichtlich ihrer Beschäftigten, ihres Publikums und der ideologischen Rahmung des Verbraucherinteresses. Nur die "politisch unabhängige" Test-Achats schloss sich der International Organization of Consumer Unions (IOCU) an, obgleich sie zunächst kleiner und weniger durchsetzungsfähig war als die Union Féminine, der sozialdemokratischen Alternative. Eine vergleichende Analyse der belgischen Verbraucherbewegung zeigt, wie das Verbraucherinteresse nach 1957 schrittweise und entsprechend hegemonialer Definitionen neu gerahmt wurde. In einem komplexen transatlantischen Dialog wurde ein privater und kommerzieller Ansatz der Verbrauchervertretung aktiv gefördert und gegen einen öffentlichen Ansatz durchgesetzt. Weiter wird in dem Beitrag argumentiert, dass die internationalen Verbindungen der beiden Organisationen - beziehungsweise das Fehlen solcher Verbindungen - wesentlich zur Erklärung ihres Erfolgs beziehungsweise ihres Scheiterns beitragen. Die Ausbreitung der Verbraucherbewegung während der I950er und I960er Jahre war finanziell und ideologisch an den keynesianisch-fordistischen Regulationsrahmen gekoppelt. Der Angriff auf den eingebetteten Liberalismus, zu dem es in den späten I970er Jahren kam, stellte die Bewegung damit vor ernsthafte Herausforderungen. Die Nachzeichnung der Entscheidungen und Entwicklunsgverläufe belgischer Verbraucheraktivisten im internationalen Kontext trägt zu einem genaueren Verständnis dieser Herausforderungen bei.

Übersetzung: Max Henninger

Giselle Nath. ¿Reproducir o disputar lo global? Las organizaciones de defensa de los consumidores belgas y sus implicaciones internacionales (1957-1995).

Entre 1957 y 1984 los consumidores belgas estaban representados por dos organizaciones dedicadas al análisis comparativo de productos: Test-Achats y la Union Féminine pour l'Information et la Défense du Consommateur. Estas dos organizaciones de defensa de los consumidores eran diferentes fundamentalmente en lo que se refiere a sus colaboradores, sus públicos y sus marcos ideológicos en cuanto a la defensa de los consumidores. De ellas sólo la "políticamente independiente" Test-Achats se adhirió a la International Organization of Consumer Unions (IOCU), incluso aunque 
inicialmente era más pequeña y más débil que la Union Fémenine que sería la alternativa socialdemócrata en estas organizaciones de consumidores. Un análisis comparativo de estas organizaciones de defensa de los consumidores nos revela como, tras I957, los intereses de las prácticas de consumo fueron gradualmente ajustándose para encajar en el marco de una definición hegemónica. Un modelo privado y comercial de la representación del consumidor fue promovido de forma activa sobre y frente a un modelo público por medio de un complejo diálogo transatlántico. Además, en el texto se plantea que las conexiones internacionales - o la ausencia de ellas - de estas dos organizaciones son un elemento esencial para explicar su éxito (o su fracaso). La expansión de la defensa organizada de los consumidores entre las décadas de i950 y I 960 estaba financieramente e ideológicamente conectada con el marco regulador del fordismo-keynesiano. El ataque contra el liberalismo enmarcado a finales de la década de 1970 implicó un desafío muy importante. Obervar las opciones y las trayectorias de estos activistas en Bélgica dentro de un contexto internacional puede sernos de ayuda a la hora de comprender mucho mejor aquel desafío.

Traducción: Vicent Sanz Rozalén 